\title{
Measurement of betacellulin levels in bovine serum, colostrum and milk
}

\author{
S E P Bastian, A J Dunbar, I K Priebe, P C Owens ${ }^{1}$ \\ and $C$ Goddard ${ }^{2}$
}

Cooperative Research Centre for Tissue Growth and Repair, CSIRO Health Sciences and Nutrition, PO Box 10041, Adelaide BC, SA 5000, Australia
${ }^{1}$ Department of Obstetrics and Gynaecology, University of Adelaide, Adelaide, SA 5005, Australia
${ }^{2}$ GroPep Limited, 28 Dalgleish Street, Thebarton, SA 5031, Australia
(Requests for offprints should be addressed to S E P Bastian, Cooperative Research Centre for Tissue Growth and Repair, PO Box 10041, Adelaide BC,
SA 5000, Australia; Email: sue.bastian@gropep.com.au)

\begin{abstract}
Betacellulin, a member of the epidermal growth factor (EGF) family, was originally isolated and identified from the conditioned medium from a murine pancreatic $\beta$-cell carcinoma cell line. Recently, we isolated bovine betacellulin from a growth factor enriched cheese whey extract, but there is no information on the presence of betacellulin in other biological fluids. We have cloned the cDNA for bovine betacellulin, produced recombinant betacellulin and shown that it has a similar potency to the purified native molecule in stimulating the proliferation of Balb/ c3T3 fibroblasts. We have produced a polyclonal antiserum to bovine betacellulin which did not cross-react with EGF or transforming growth factor- $\alpha$ (TGF- $\alpha$ ). The antibody was used in a homologous RIA that was able to detect betacellulin in pooled bovine colostrum sampled during the first 3 days after calving $(2 \cdot 30 \pm 0 \cdot 11 \mathrm{ng} / \mathrm{ml}$ mean \pm s.E.M.; $n=6$ ), in bovine milk soluble fraction $(1.93 \pm 0.64 \mathrm{ng} / \mathrm{ml}$ mean \pm s.E.M.; $n=5)$ and in bovine cheese whey $(2 \cdot 59 \pm 0 \cdot 16 \mathrm{ng} / \mathrm{ml}$ mean \pm s.E.M.; $n=3)$. The betacellulin concentration in foetal bovine serum (FBS) $(3.68 \pm 0.59 \mathrm{ng} / \mathrm{ml}$ mean \pm S.E.M.; $n=6)$ greatly
\end{abstract}

exceeded that of betacellulin in serum from male calves 1 and 5 weeks of age $(0.53 \pm 0.15 \mathrm{ng} / \mathrm{ml}$ and $0.70 \pm$ $0 \cdot 09 \mathrm{ng} / \mathrm{ml}$ respectively; mean \pm S.E.M.; $n=9$ ). Betacellulin measured in the serum of these same animals when aged between 27 and 43 weeks was below the detection limits of the RIA. Sera from 10 out of 36 unmated heifers contained betacellulin levels within the detection limits of the assay $(0 \cdot 433 \pm 0 \cdot 06 \mathrm{ng} / \mathrm{ml}$ mean \pm S.E.M.; $n=10)$. The presence of betacellulin in bovine colostrum and milk suggests that it plays a role in the growth and development of the neonate and/or mammary gland function. The results also show that betacellulin is undetectable in the castrated adult male circulation. Additionally, although present in very low amounts, serum betacellulin could be under hormonal regulation in the female, since betacellulin was detected in sera from $27 \%$ of the unmated heifers examined in this study. The high levels of betacellulin detected in FBS relative to newborn and adult serum suggests a possible endocrine role for this growth factor in the bovine foetus.

Journal of Endocrinology (2001) 168, 203-212

\section{Introduction}

Betacellulin was first isolated as a mitogen in the conditioned medium of a mouse pancreatic $\beta$-cell carcinoma cell line (Shing et al. 1993). Mouse betacellulin is a $32 \mathrm{kDa}$ glycosylated polypeptide composed of 80 amino acids which shares $82.5 \%$ and $79 \%$ amino acid sequence identity with the human and bovine form respectively (Shing et al. 1993, Watanabe et al. 1994, Dunbar et al. 1999). Betacellulin is one of the epidermal growth factor (EGF) family of growth factors. The other members include amphiregulin, epiregulin, heparin-binding EGF-like growth factor (HB-EGF), neural- and thymus-derived activator for erbB kinases (NTAK), the neuregulin gene products and transforming growth factor- $\alpha$ (Marchionni et al. 1993, Carraway et al. 1997, Chang et al. 1997, Higashiyama et al. 1997, Raab \& Klagsbrun 1997, Zhang et al. 1997). Betacellulin shares significant sequence homology with the other members, including a characteristic six-cysteine consensus motif within the EGF-like domain, which forms three intra-molecular disulphide bonds. Another common feature of the EGF family members is that they are produced as transmembrane precursor molecules and are proteolytically cleaved to give rise to the soluble mature growth factor. Betacellulin is able to bind and activate members of the EGF tyrosine kinase receptor family encoded by the erbB genes, specifically, erbB-1 (EGFR) and erbB-4 (Watanabe et al. 1994, Riese et al. 1996). It has 
since been demonstrated that betacellulin is not only able to activate homodimers of erbB-1 and erbB-4, but also combinations of erbB receptor heterodimers, including the oncogenic erbB-2-erbB-3 complex (Alimandi et al. 1997).

Betacellulin is expressed predominantly in pancreas and small intestine but also weakly in heart, lung, liver, skeletal muscle, kidney, prostate, testis, ovary and colon (Sasada et al. 1993, Seno et al. 1996). It is a known mitogen for numerous cell types including smooth muscle cells, Balb/ c3T3 cells, Madin Darby canine kidney epithelial cells and retinal pigment epithelial cells (Shing et al. 1993). Despite this knowledge the biological role of betacellulin in vivo is not yet understood.

Bovine milk is rich in a number of growth factors including platelet-derived growth factor (PDGF) and the insulin-like growth factors, IGF-I and IGF-II (Shing \& Klagsbrun 1984, Francis et al. 1988). Previous studies in this laboratory have produced a novel whey extract that comprises a concentrated mixture of bovine milk proteins enriched in growth factors (Francis et al. 1995). This extract is a source of potent growth-promoting activity for a number of mesoderm-derived cell types (Belford et al. 1995). A recent study by Dunbar et al. (1999) has since found that betacellulin accounts for about $50 \%$ of the growth-promoting activity within this extract when tested in a Balb/3T3 bioassay.

The implication of this finding is that betacellulin is present in bovine milk. Taken together with its role as a mitogenic factor for a number of cell types and its expression, along with its receptors in numerous tissues, suggests a major biological role. Receptors for betacellulin have been demonstrated in liver and placental tissue (O'Keefe et al. 1974, Wang et al. 1992, Mielke et al. 1998), which raises the possibility that betacellulin, may be in the circulation. Using a homologous RIA for bovine betacellulin, we were able to confirm the presence and determine the levels of betacellulin in bovine colostrum and milk. Additionally, we demonstrated the presence of betacellulin in serum, and the effects of age and sex of the animal on the serum betacellulin concentration.

\section{Materials and Methods}

\section{Production of recombinant bovine betacellulin}

A modification of the expression vector $\mathrm{p}\left[\mathrm{Met}^{1}\right]-\mathrm{pGH}$ (1-46)IGF-I (King et al. 1992) was used to produce recombinant bovine betacellulin. This plasmid directs isopropyl-D-galactoside (IPTG)-induced high-level expression of betacellulin as a fusion protein that has a 46 amino acid amino-terminal extension derived from methionyl porcine growth hormone ( $\mathrm{pGH}$ ). A modification was made to introduce a methionine in-between the fusion partner and betacellulin so that the fusion protein could be cleaved to release authentic bovine betacellulin, following proteolytic digestion with cyanogen bromide.
The cDNA encoding the complete nucleotide sequence of mature bovine betacellulin $\left[\mathrm{Asp}^{1}-\mathrm{Tyr}^{80}\right.$ ] was generated by RT-PCR. Total RNA was isolated from 80-90\% confluent Madin Darby bovine kidney cells (MDBK, ATCC CCL 22) and cDNA synthesized from $1 \mu \mathrm{g}$ total MDBK RNA using oligo dT primer and Superscript II (Life Technologies, Melbourne, Australia). The subsequent cDNA was used as a template for PCR with oligonucleotide primers, 5' ATC TAG GTT ACC ATG GAT GGG AAT TCA ACC AGA $3^{\prime}$ and $5^{\prime}$ CTA GAT AAG CTT TCA TCA GTA AAA CAA GTC AAC TCT $3^{\prime}$. The resultant 273 bp PCR product was purified, digested with $\mathrm{HpaI}$ and HindIII and cloned into the HpaI/HindIII digested expression vector $\mathrm{p}\left[\mathrm{Met}^{1}\right]-$ $\mathrm{pGH}(1-46)$. The recombinant plasmid was maintained in E. coli, strain JM101.

The E. coli JM101 strain harbouring the plasmid $\mathrm{p}\left[\mathrm{Met}^{1}\right]-\mathrm{pGH}(1-46)-$ Val-Asn-Met-betacellulin was selected as a single colony and used to inoculate a $20 \mathrm{ml}$ starter culture in a medium $\left(\mathrm{K}_{2} \mathrm{HPO}_{4} 60 \mathrm{mM}, \mathrm{KH}_{2} \mathrm{PO}_{4}\right.$ $33 \mathrm{mM},\left(\mathrm{NH}_{4}\right)_{2} \mathrm{SO}_{4} 7.5 \mathrm{mM}$, sodium citrate $1.7 \mathrm{mM}$, $\mathrm{MgSO}_{4} \cdot 7 \mathrm{H}_{2} \mathrm{O} 10 \mu \mathrm{M}$, D-glucose $0 \cdot 2 \%$, thiamine $0.0005 \%$, ampicillin $50 \mu \mathrm{g} / \mathrm{ml}$ ). The culture was grown at $37^{\circ} \mathrm{C}$ for $16 \mathrm{~h}$. The starter culture was in turn used to inoculate two 51 fermenters (Applikon, Schiedam, The Netherlands) each containing 31 of growth medium $\left(\mathrm{NH}_{4} \mathrm{Cl} 30 \mathrm{mM}, \quad \mathrm{K}_{2} \mathrm{SO}_{4} 7 \mathrm{mM}, \quad \mathrm{KH}_{2} \mathrm{PO}_{4} 12 \mathrm{mM}\right.$, $\mathrm{Na}_{2} \mathrm{HPO}_{4} 19 \mathrm{mM}$, D-glucose $139 \mathrm{mM}, \mathrm{MgSO}_{4} \cdot 7 \mathrm{H}_{2} \mathrm{O}$ $2.4 \mathrm{mM}$, thiamine $0.0004 \%, \mathrm{Fe}_{2} \mathrm{SO}_{4} .7 \mathrm{H}_{2} \mathrm{O} 35 \mu \mathrm{M}$, $\mathrm{MnSO}_{4} \cdot 7 \mathrm{H}_{2} \mathrm{O} \quad 7 \cdot 4 \mu \mathrm{M}, \quad \mathrm{CuSO}_{4} \cdot 7 \mathrm{H}_{2} \mathrm{O} \quad 0 \cdot 8 \mu \mathrm{M}$, trisodium citrate $74 \mu \mathrm{M}$ and ampicillin $50 \mu \mathrm{g} / \mathrm{ml}$ ). Bacteria were grown at $37^{\circ} \mathrm{C}$ until the absorbance at $600 \mathrm{~nm}$ reached an OD of 4.0 and then induced with IPTG $(0.33 \mathrm{mM})$ and the cultivation was continued until glucose became limiting, indicated by a sharp rise in $\mathrm{pH}$. Regulation of temperature, $\mathrm{pH}$ and oxygen was under automatic control (FC4 Data system, Real Time Engineering, Sydney, Australia). Cells were disrupted at 5000 p.s.i. following five passes through a homogenizer (Rannie Instruments, APV Homogenisers, Albertslund, Denmark) and inclusion bodies collected by centrifugation (10 000 r.p.m., $25 \mathrm{~min}, 4^{\circ} \mathrm{C}$ ). The inclusion bodies were washed twice with $\mathrm{NaCl}(30 \mathrm{mM}), \mathrm{KH}_{2} \mathrm{PO}_{4}(10 \mathrm{mM})$, $\mathrm{ZnCl}_{2} \quad(0.5 \mathrm{mM})$, harvested by centrifugation at 6000 r.p.m. and stored at $-80{ }^{\circ} \mathrm{C}$.

Washed inclusion bodies, in $20 \mathrm{~g}$ batches, were thawed, suspended at $10 \%(\mathrm{w} / \mathrm{v})$ in a buffer containing urea $(8 \mathrm{M})$, Tris- $\mathrm{HCl} \quad(0 \cdot 1 \mathrm{M})$, glycine $(40 \mathrm{mM})$, dithiothreitol $(40 \mathrm{mM})$ and $\mathrm{ZnCl}_{2}(0.5 \mathrm{mM})(\mathrm{pH} 9 \cdot 0)$ and stirred for $30 \mathrm{~min}$ at room temperature. The solubilized inclusion bodies were centrifuged at 14000 r.p.m. for $20 \mathrm{~min}$ and the resultant supernatant desalted on a XK column $(5 \mathrm{~cm}$ $\times 100 \mathrm{~cm}$; Amersham Pharmacia Biotech, Sydney, Australia) packed with Cellufine GCL-1000 (Chisso Corporation, Tokyo, Japan) and equilibrated with urea $(8 \mathrm{M})$, Tris- $\mathrm{HCl}(0 \cdot 1 \mathrm{M})$, glycine $(40 \mathrm{mM})$, dithiothreitol 
$(1.6 \mathrm{mM})$ and $\mathrm{ZnCl}_{2}(0.5 \mathrm{mM})(\mathrm{pH} 9.0)$ at a flow rate of $2 \mathrm{ml} / \mathrm{min}$. Thirty millilitre fractions were collected and those containing recombinant $\left[\mathrm{Met}^{1}\right]-\mathrm{pGH}(1-46)-$ Metbetacellulin fusion protein were pooled and subject to oxidative refolding by diluting the pool to a final protein concentration of $0.1 \mathrm{mg} / \mathrm{ml}$ in buffer containing urea $(4 \mathrm{M})$, glycine $(40 \mathrm{mM}), \quad$ Tris- $\mathrm{HCl} \quad(0.1 \mathrm{M})$, EDTA $(5 \mathrm{mM})$, dithiothreitol $(0.4 \mathrm{mM})$ and 2hydroxethyldisulphide $(1 \mathrm{mM})(\mathrm{pH} 9 \cdot 0)$. After stirring for $3 \mathrm{~h}$ at room temperature, the reaction was stopped by adjusting the $\mathrm{pH}$ to 6.45 with $\mathrm{HCl}(1 \mathrm{M})$. The refolded fusion protein was further purified on a S-Sepharose Fast Flow column $(5 \mathrm{~cm} \times 15 \mathrm{~cm}$; Amersham Pharmacia Biotech) equilibrated with urea $(8 \mathrm{M})$, ammonium acetate $(50 \mathrm{mM})(\mathrm{pH} 6.45)$ at a flow rate of $15 \mathrm{ml} / \mathrm{min}$. The column was washed with the same buffer until the optical density $\left(\mathrm{OD}_{280 \mathrm{~nm}}\right)$ returned to baseline. The column was then eluted with a linear gradient of $\mathrm{NaCl}(0-0.7 \mathrm{M})$ in the same buffer at a flow rate of $15 \mathrm{ml} / \mathrm{min}$. Fractions of $30 \mathrm{ml}$ were collected and those containing fusion protein pooled. The fusion protein pool was desalted and further purified by HPLC on a $\mathrm{C}_{4}$ Prep-Pak column $(40 \mathrm{~mm}$ $\times 100 \mathrm{~mm} ; 300 \AA$ A pore size, $15 \mu \mathrm{m}$ bead size; MilliporeWaters, Lane Cove, Australia). The protein pool was adjusted to $0 \cdot 1 \%$ trifluoroacetic acid (TFA) and loaded onto the $\mathrm{C}_{4}$ column at $50 \mathrm{ml} / \mathrm{min}$. The column was washed extensively with $0 \cdot 1 \%$ TFA and protein eluted with a gradient of $18-50 \%(\mathrm{v} / \mathrm{v})$ acetonitrile over $90 \mathrm{~min}$ in the presence of $0.08 \%$ TFA at a flow rate of $20 \mathrm{ml} / \mathrm{min}$. Fractions of $30 \mathrm{ml}$ were collected and those containing fusion protein pooled and lyophilized.

To produce authentic bovine betacellulin, the fusion protein was cleaved by solubilizing the lyophilized protein in $\mathrm{HCl}(0.13 \mathrm{M})$ containing a 100 -fold molar excess of cyanogen bromide at a protein concentration of $10 \mathrm{mg} / \mathrm{ml}$. The cleavage reaction was performed at room temperature in the dark for $25 \mathrm{~h}$. Authentic betacellulin was separated from its fusion partner by HPLC. The cleavage reaction was diluted 1:4 (v/v) with $0 \cdot 1 \%$ TFA and applied to a $\mathrm{C}_{4}$ Prep-Pak column (Millipore-Waters) at a flow rate of $50 \mathrm{ml} / \mathrm{min}$. The column was washed with $0 \cdot 1 \%$ TFA until $\mathrm{OD}_{280 \mathrm{~nm}}$ returned to baseline and the column was then eluted with a gradient of $16-32 \%(\mathrm{v} / \mathrm{v})$ acetonitrile over $150 \mathrm{~min}$ in the presence of $0.08 \%$ TFA at a flow rate of $20 \mathrm{ml} / \mathrm{min}$. Fractions of $26 \mathrm{ml}$ were collected and those containing pure betacellulin pooled.

\section{Cell culture}

Balb/c3T3 fibroblasts (CCL 163) were purchased from American Type Culture Collection (Rockville, MD, USA). Cells were grown in DMEM containing 10\% foetal bovine serum (FBS), together with $100 \mathrm{mg}$ streptomycin, $60 \mathrm{mg}$ penicillin and $1 \mathrm{mg}$ fungizone per litre of growth medium (CSL Limited, Parkville, Australia). All cells were grown and used for experiments as monolayers at $37^{\circ} \mathrm{C}$ in $5 \% \mathrm{CO}_{2}$.

The ability of recombinant bovine betacellulin to promote proliferation of cell monolayers was determined using a 96-well plate dye-binding assay (Oliver et al. 1989). Cells were seeded at a density of $2 \times 10^{5}$ cells $/ \mathrm{ml}$ and incubated overnight in the appropriate media to facilitate cell attachment. Cells were washed thoroughly to remove residual media prior to addition of the indicated concentrations of purified native bovine betacellulin (Dunbar et al. 1999) or recombinant bovine betacellulin, which had been diluted in serum-free media containing BSA (Sigma-Aldrich, St Louis, MO, USA, 0.1\% (w/v)). A FBS-positive control was included on each plate. Cells were incubated in the presence of growth factor for $48 \mathrm{~h}$, washed twice with $\mathrm{NaCl}(150 \mathrm{mM})$, fixed with methanol, stained with $1 \%(\mathrm{w} / \mathrm{v})$ methylene blue (Sigma-Aldrich) and the absorbance read at $655 \mathrm{~nm}$. Data are expressed as the percentage of the growth response observed in serumfree medium and plotted using SigmaPlot version 4.0 (Jandel Scientific, San Rafael, CA, USA).

\section{Antibody production}

Antibody production was approved by the Animal Ethics Committee of the Women's and Children's Hospital, Adelaide, SA, Australia. Three female New Zealand semi-lop rabbits were obtained from the Institute of Medical and Veterinary Sciences (Gilles Plains, SA, Australia). Each rabbit was injected subcutaneously at five different sites around the shoulder and neck with $500 \mu \mathrm{g}$ of recombinant bovine betacellulin in Freund's complete adjuvant (Sigma-Aldrich). After 6 weeks, animals were given a first booster injection of $100 \mu \mathrm{g}$ betacellulin in Freund's incomplete adjuvant (Sigma-Aldrich) and a similar, second boost, 4 weeks later. Blood samples were obtained 2 weeks after each booster injection for determination of antibody titre. Animals were sacrificed 4 weeks after the second booster and blood was collected by cardiac puncture.

\section{RIA}

Recombinant bovine betacellulin was iodinated with carrier-free $\mathrm{Na}\left[{ }^{125} \mathrm{I}\right]$ (Amersham Pharmacia Biotech), to a specific activity of $65 \mu \mathrm{Ci} / \mu \mathrm{g}$ using a modification of the chloramine T method (Gargosky et al. 1990).

A betacellulin standard curve was prepared by dilution of a frozen stock solution $(50 \mathrm{ng} / \mathrm{ml})$. The range of the standard curve was from 4.9 to $5000 \mathrm{pg} /$ tube. Each tube contained either $100 \mu \mathrm{l}$ of assay buffer $\left(\mathrm{NaH}_{2} \mathrm{PO}_{4} 30 \mathrm{mM}\right.$, protamine sulphate $0 \cdot 2 \%(\mathrm{w} / \mathrm{v})$, disodium EDTA $10 \mathrm{mM}$, $\mathrm{NaN}_{3}$ 0.2\% (w/v), Tween-20 0.05\% (w/v), pH 7·5), $100 \mu \mathrm{l}$ sample or $100 \mu \mathrm{l}$ standard in assay buffer, $25 \mu \mathrm{l}$ ${ }^{125}$ I-labelled betacellulin (approximately 20000 c.p.m.) in assay buffer and $25 \mu \mathrm{l}$ of betacellulin antiserum (1:50 000) 
in assay buffer (final dilution 1:300 000). The tubes were mixed and incubated for $16 \mathrm{~h}$ at $4{ }^{\circ} \mathrm{C}$. A $50 \mu \mathrm{l}$ aliquot of goat anti-rabbit IgG (GroPep Limited, Adelaide, Australia) in assay buffer and $10 \mu \mathrm{l}$ of rabbit immunoglobulin (Dako Corporation, Carpinteria, CA, USA) pre-diluted $1: 200 \mathrm{v} / \mathrm{v}$ in assay buffer, were added to each tube and incubated for a further $30 \mathrm{~min}$ at $4{ }^{\circ} \mathrm{C}$. Precipitation of bound betacellulin was assisted by the addition of $1 \mathrm{ml}$ ice-cold polyethylene glycol $6000(6 \%(\mathrm{w} / \mathrm{v})$ in $150 \mathrm{mM}$ $\mathrm{NaCl}$ ) and the tubes centrifuged at $4000 \boldsymbol{g}$ for $20 \mathrm{~min}$ at $4{ }^{\circ} \mathrm{C}$. The supernatant was removed by aspiration and radioactivity in the remaining pellet measured using a Model 1470 Gamma Counter (Wallac Oy, Turku, Finland). The concentration of betacellulin in each tube was calculated using RIAcalc software (Wallac Oy). Unknown samples and standards were measured in triplicate.

\section{Sample preparation}

The nine Friesian Holstein bulls used in this study were castrated at 10 weeks of age and their blood samples collected by jugular venipuncture on several occasions between 1 and 43 weeks. These animals were maintained at the University of Queensland, Pastoral and Veterinary Centre, Goondiwindi, NSW, Australia and were fed Ultragrow calf milk replacer (Millmaster Feeds, Tamworth, NSW, Australia), had access to hay and allowed to feed ad libitum, and were offered Ultragrow calf pellets (Millmaster Feeds) once daily for the first 6 weeks before being weaned off milk replacer. The Animal Ethics Committee of the University of Queensland approved the sample collection. Blood samples were also collected by coccygeal venipuncture from 36 unmated Friesian Holstein heifers with a mean age of $50.5 \pm 2 \cdot 0$ weeks (mean \pm S.E.M.) from the Roseworthy Campus dairy herd, University of Adelaide. The Animal Ethics Committee of the University of Adelaide approved the sample collection. Blood samples were allowed to clot at $4{ }^{\circ} \mathrm{C}$ for $16 \mathrm{~h}$, centrifuged at $4000 \mathrm{~g}$ at $4{ }^{\circ} \mathrm{C}$ for $20 \mathrm{~min}$ and the serum collected for analysis. Six distinct batches of FBS for measurement of betacellulin concentration were obtained from Trace Scientific (Melbourne, Australia).

Bovine colostrum and milk were collected from cows with an average age of $225 \cdot 26 \pm 49 \cdot 54$ weeks (mean \pm S.E.M.; $n=11$ ). Colostrum from six cows was collected at the morning and afternoon milking for the first 3 days after calving and stored at $-20{ }^{\circ} \mathrm{C}$. Samples were prepared for measurement of betacellulin using an adaptation of the method of Francis et al. (1988). Samples were thawed, centrifuged at $21000 \mathrm{~g}$ for $30 \mathrm{~min}$ at $4{ }^{\circ} \mathrm{C}$ and the resulting infranatant mixed with 0.33 volumes of Freon[1,1,2-trichloro-1,2,2,-trifluoroethane] (Dupont Wilmington, MA, USA) for $15 \mathrm{~min}$. A further centrifugation step performed at $4000 \mathrm{~g}$ for $15 \mathrm{~min}$ at $4{ }^{\circ} \mathrm{C}$, yielded a clear supernatant that was subsequently adjusted to $\mathrm{pH} 4$ with $\mathrm{HCl}(1 \mathrm{M})$. The acidified supernatant was centrifuged again for $30 \mathrm{~min}$ at $21000 \mathrm{~g}$ at $4{ }^{\circ} \mathrm{C}$ and the resultant supernatant neutralized with $\mathrm{NaOH}(1 \mathrm{M})$. Milk from five different cows was taken more than 1 week after calving and used to prepare bovine milk soluble fraction (BMSF). Separated, clarified and pasteurized bovine cheddar cheese whey was sourced from National Foods (Murray Bridge, SA, Australia). Preparation of BMSF and bovine cheddar cheese whey samples for RIA was achieved using the same method used for preparation of colostrum. Total protein content in colostrum, BMSF and whey was quantified using the BCA Protein Assay Kit (Pierce, Rockford, IL, USA).

\section{Results}

Analysis of the final betacellulin protein pool by microbore $\mathrm{C}_{4}$ reverse-phase HPLC identified a single protein peak (Fig. 1). The purity of the betacellulin preparation was further confirmed by N-terminal sequence analysis which concurred with the predicted sequence for bovine betacellulin (Dunbar et al. 1999) with an approximate purity of $>99 \%$. The molecular mass of recombinant betacellulin determined by electrospray ionization mass spectrometry was $8995 \cdot 1 \pm 0 \cdot 83$. This is consistent with the theoretical mass of 8995.02 calculated from the betacellulin amino acid sequence. Following SDS-PAGE analysis, a single protein band of approximately $9 \mathrm{kDa}$ was detected under reducing or non-reducing conditions (Fig. 1, inset).

The biological activity of purified native bovine betacellulin (Dunbar et al. 1999) was compared with that of recombinant bovine betacellulin in Balb/c3T3 fibroblasts. Recombinant betacellulin stimulated the proliferation of $\mathrm{Balb} / \mathrm{c} 3 \mathrm{~T} 3$ cells in a dose-dependent manner similar to the native betacellulin (Fig. 2). Half maximal stimulation of Balb/c3T3 cell proliferation was observed at $1.98 \mathrm{ng} / \mathrm{ml}$ and $3.29 \mathrm{ng} / \mathrm{ml}$ for native betacellulin and recombinant betacellulin respectively.

Antibody dilution curves were constructed by diluting each individual antiserum in assay buffer and measuring its ability to bind ${ }^{125}$ I-betacellulin. All rabbits raised a highly significant antibody response against recombinant bovine betacellulin. Only one antiserum was chosen for use in the development of a RIA, based on the half-maximum binding of the label at a dilution of 1:300 000 and the absence of any cross-reactivity to related ligands. The antiserum was able to detect recombinant bovine betacellulin to a much greater degree than recombinant human betacellulin (R\&D Systems, Minneapolis, MN, USA) by Western immunoblotting (results not shown). The competition between bovine betacellulin, recombinant human EGF and recombinant human transforming growth factor- $\alpha$ (TGF- $\alpha$ ) (GroPep Limited) with ${ }^{125}$ I-betacellulin for binding sites on the polyclonal antiserum raised against recombinant bovine betacellulin is shown in Fig. 3a. Half 


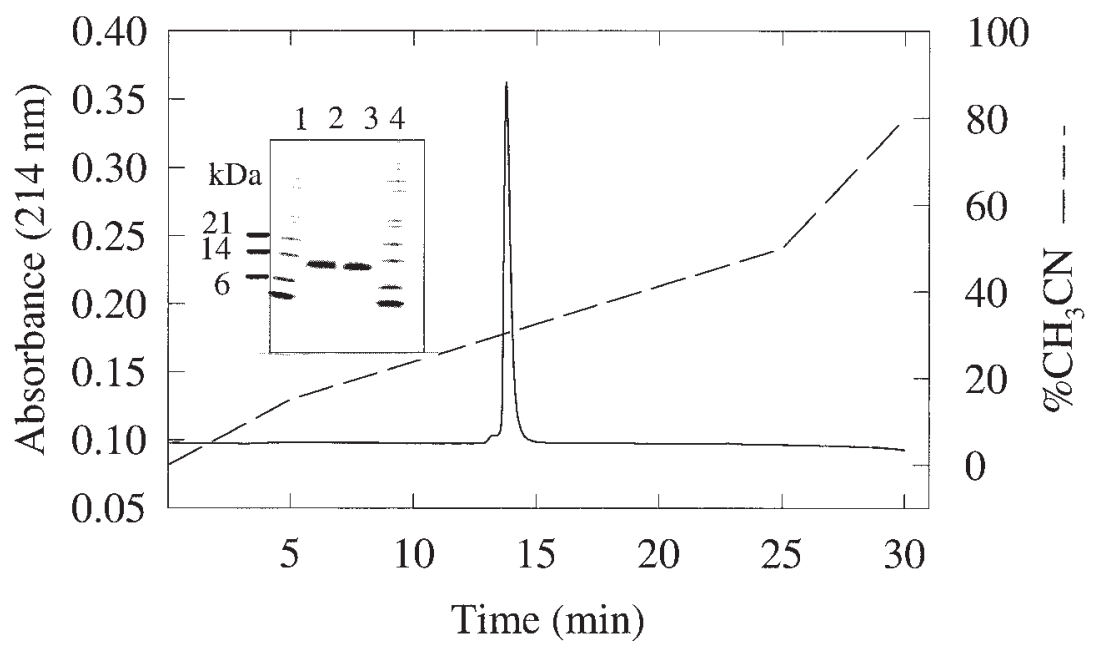

Figure 1 Reverse-phase HPLC of purified recombinant bovine betacellulin. Inset: SDS-PAGE analysis of the purified preparation under reducing (lane 2) or non-reducing conditions (lane 3); lanes 1 and 4, molecular weight markers.

maximal displacement for bovine betacellulin occurred at $0.78 \mathrm{ng} / \mathrm{ml}$. There was no cross-reactivity with human EGF and human TGF- $\alpha$. The displacement curve for bovine betacellulin was compared with that of serial dilutions of FBS in the RIA. This demonstrated that the serum dilution curve was parallel to the betacellulin standard curve (Fig. 3b). Similar dilution curves of colostrum and milk samples were also parallel to the standard curve (results not shown). The coefficients of variation within and between assays for bovine betacellulin were $3.95 \%$ and $8 \cdot 50 \%$ respectively.

Colostrum sampled from each of the five animals on days 1, 2 and 3 after calving was pooled according to day of sampling, processed as described and the betacellulin levels measured by RIA. The concentration of betacellulin in day 1,2 and 3 colostrum pools did not differ significantly (Table 1) although, as expected, the total protein content of colostrum decreased significantly between day 1 and the day 2 and 3 samples $(P<0 \cdot 001)$. When expressed as a percentage of total colostral protein, betacellulin levels increased significantly over the 3 days. Bovine milk soluble fraction and bovine cheese whey had levels of betacellulin similar to that found in colostrum (Table 1).

The betacellulin concentrations in six different batches of FBS were determined using the RIA (Table 1). The mean \pm S.E.M. betacellulin concentration for FBS was $3.68 \pm 0.59 \mathrm{ng} / \mathrm{ml}$. This was significantly higher than in serum pooled from calves at 1 week and 5 weeks of age, which were $0.53 \pm 0.15 \mathrm{ng} / \mathrm{ml}$ and $0.70 \pm 0.09 \mathrm{ng} / \mathrm{ml}$ respectively (Fig. 4). The serum betacellulin concentration in these same animals when aged between 27 and 43 weeks was below the minimum detection limit of the assay (indicated by a solid horizontal line across the graph). Sera from 10 out of the 36 unmated heifers contained betacellulin levels within the detection limits of the assay $(0 \cdot 433 \pm 0 \cdot 06$ mean \pm s.E.M., $n=10)$ (Fig. 4). The results demonstrate that using this homologous RIA, betacellulin is present at high levels in FBS but is undetectable in serum from male cattle over 5 weeks of age. Interestingly, only $27 \%$ of the unmated female animals tested contained detectable levels of serum betacellulin.

\section{Discussion}

We believe that this is the first study to report the presence of betacellulin by homologous RIA in bovine colostrum and milk. Other members of the epidermal growth factor family have been detected in the colostrum and milk of several species. Specifically, studies have reported the presence of EGF in human (Jansson et al. 1985, Read et al. 1985, Iacopetta et al. 1992), pig (Jaeger et al. 1987), rat (Raaberg et al. 1990), mouse (Grueters et al. 1985) and wallaby (Ballard et al. 1995) colostrum and milk and TGF- $\alpha$ in human milk (Connolly \& Rose 1988, Okada et al. 1991).

Of more relevance to the present study is the earlier finding where EGF activity was detected in bovine colostrum and milk. However, unlike human milk where EGF is a predominant growth factor (Carpenter 1980), PDGF, IGF-I and -II rich bovine milk (Shing \& Klagsbrun 1984, Francis et al. 1988) appears to contain very little EGF (Iacopetta et al. 1992). On average, the colostrum samples analysed in the present study contained approximately $2 \cdot 3 \mathrm{ng} / \mathrm{ml}$ betacellulin, whereas EGF levels of approximately $6 \mathrm{ng} / \mathrm{ml}$ have been previously reported (Read et al. 1984, Iacopetta et al. 1992). EGF concentrations reported in milk vary considerably, most probably 


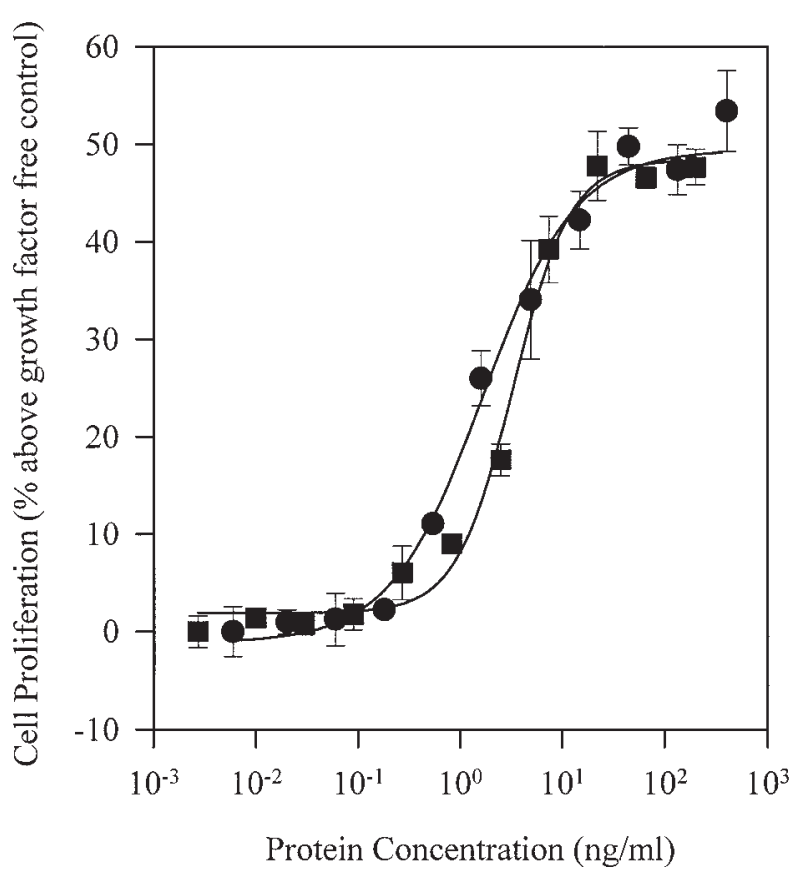

Figure 2 Proliferation of Balb/c3T3 cells in response to purified native bovine betacellulin $(\mathbf{)})$ or recombinant bovine betacellulin (ם). Cells were seeded for $16 \mathrm{~h}$ in media supplemented with FBS. They were washed in serum-free media, followed by addition of the indicated concentrations of growth factor in serum-free media. After a further $48 \mathrm{~h}$ incubation, cell density was measured using a methylene blue dye-binding assay. Results are expressed as the percentage increase in absorbance at $655 \mathrm{~nm}$ above the growth factor free control. Data points represent the means of triplicate determinations and error bars indicate the S.E.M. where greater than the symbol size.

as a result of the use of different assay systems. Using a radioreceptor assay with a human lung fibroblast cell line as a source of EGF receptors, Read et al. (1984) determined that pasteurized bovine milk contained approximately $2.5 \mathrm{ng} / \mathrm{ml}$ EGF. In another study using placental plasma membranes, Yagi et al. (1986) estimated that bovine milk contained $320 \mathrm{ng} / \mathrm{ml}$ EGF. Subsequent studies by Iacopetta et al. (1992) showed that radioreceptor assays performed with placental plasma membranes to measure EGF in bovine milk produced unreliable results, but using the A431 cell line found that bovine milk contained less than $2 \mathrm{ng} / \mathrm{ml}$ EGF. Radioreceptor assays can detect proteins with EGF receptor binding capacity, but are limited in that they are unable to discern which specific EGF receptor ligand is being measured. The current homologous RIA uses an antibody that we have shown to be specific for betacellulin and using this assay we found that bovine milk contains approximately $1.93 \mathrm{ng} / \mathrm{ml}$ betacellulin. To our knowledge, no previous studies have definitively proven the presence of EGF in bovine milk. Therefore, we suggest that bovine milk does not contain EGF but instead low levels of betacellulin, and that this growth factor may be responsible in part for the bovine milk EGF receptor binding activity detected in the studies by Read et al. (1984) and Iacopetta et al. (1992).

Concentrations of other growth factors in bovine colostrum such as IGF-I, IGF-II and insulin decline substantially coincident with the fall in milk protein as early lactation proceeds (Malven et al. 1987, Vega et al. 1991, Lee et al. 1995). In contrast, studies in human milk found that TGF- $\alpha$ levels remained fairly stable for 7 days post-partum (Okada et al. 1991). Similarly, we have demonstrated that despite the decrease in total protein, colostrum betacellulin levels remain stable for the first 3 days after calving and that similar betacellulin levels occur in mature milk. Francis et al. (1995) have shown that bovine milk-derived growth factors are retained in the whey fraction. Our present studies have confirmed this finding and shown that betacellulin concentrations in separated, clarified and pasteurized whey are similar to that in colostrum and milk. The relative stability of the levels of this growth factor throughout bovine lactation suggests a role for betacellulin in the suckling neonate and in mammary function that could be major, and quite distinct from EGF.

A number of studies indicate that milk-derived EGF is required as a regulator of postnatal gut development in the suckling young of rats, mice and pigs (Berseth 1987, Popliker et al. 1987, Shen \& Xu 1996, 1998), and influences the growth and development of the post-natal liver (McCuskey et al. 1997), spontaneous intestinal bacterial translocation in newborns (Okuyama et al. 1998) and neonatal eyelid opening (Okamoto \& Oka 1985). The significance of betacellulin occurring in bovine milk for the growth and development of the suckling neonate is presently unknown, however, accumulating evidence supports a role for betacellulin in gut development as well. The erbB receptors known to bind betacellulin have been described in various sections of the gut and in gastrointestinal cancers (Quirke et al. 1989, Jankowski et al. 1992, Prigent et al. 1992, Kataoka et al. 1998, Noguchi et al. 1999), while betacellulin itself is expressed in adult gastrointestinal tract (Seno et al. 1996) and increases DNA synthesis in RIE cells (Barnard et al. 1994). We have preliminary evidence to show that betacellulin can stimulate proliferation of rat IEC-6 cells in vitro and gastrointestinal epithelial cells in vivo following systemic administration to rats.

Current knowledge also supports a potential role for betacellulin in mammary development and/or function. Transgenic animal studies have revealed that other members of the EGF family, including TGF- $\alpha$, amphiregulin and EGF, have essential roles in ductal morphogenesis and lactogenesis in mice (Luetteke et al. 1999). erbB receptors have been identified within mammary glands from numerous species including cows (Spitzer \& Grosse 1987), and Dunbar et al. (1999) have shown that betacellulin mRNA is expressed in bovine mammary tissue. 
Betacellulin stimulates the MDA-MB453 mammary epithelial cell line to differentiate and produce milk-like droplets (Pinkas-Kramarski et al. 1998). Colostrum or milk-borne betacellulin could be derived from the numerous cells present within these fluids, the maternal circulation or from synthesis within the mammary gland itself. The source of betacellulin in milk, similar to EGF, is unlikely to arise from serum because lactating serum contains much lower levels than milk (S E P Bastian,

(a)

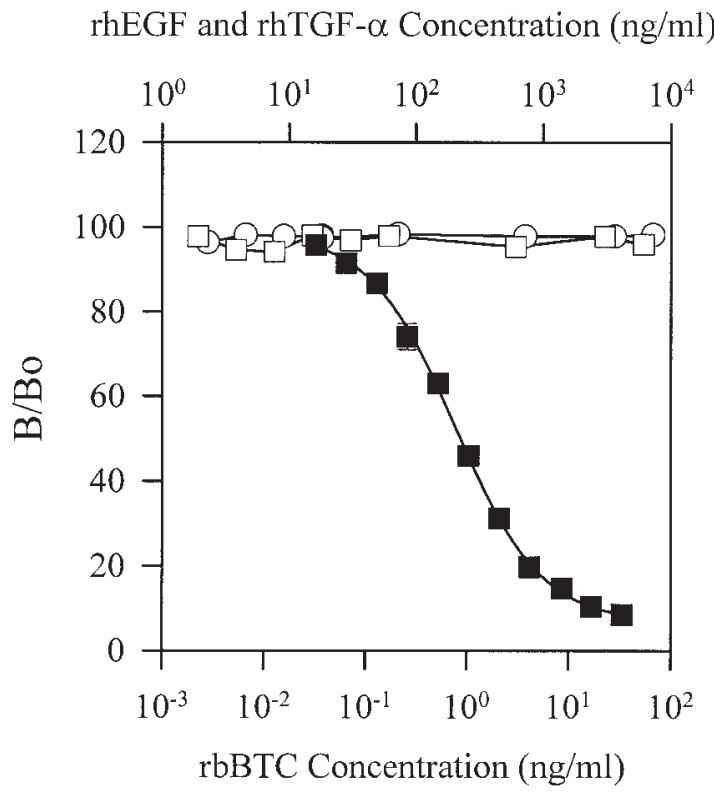

Dilution of FBS

(b)

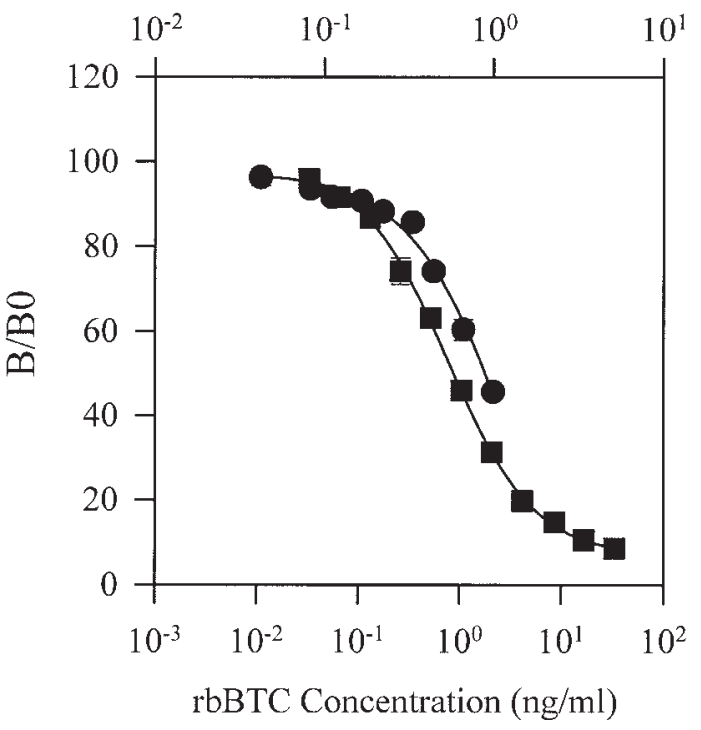

Table 1 Betacellulin and total protein concentrations of FBS pooled bovine colostrum, bovine milk soluble fraction (BMSF) and bovine cheddar cheese whey

\begin{tabular}{llc} 
& $\begin{array}{l}\text { Betacellulin concentration } \\
\text { Mean } \pm \text { S.E.M. }(\mathrm{ng} / \mathrm{ml})\end{array}$ & $\begin{array}{c}\text { Total protein } \\
\text { Mean } \pm \text { S.E.M. } \\
(\mathrm{mg} / \mathrm{ml})\end{array}$ \\
\cline { 2 - 2 } FBS & $3 \cdot 68 \pm 0 \cdot 59$ & \\
Colostrum day 1 & $2 \cdot 61 \pm 0 \cdot 41$ & $54 \cdot 5 \pm 2 \cdot 5$ \\
Colostrum day 2 & $2 \cdot 14 \pm 0 \cdot 17$ & $12 \cdot 2 \pm 0 \cdot 8^{*}$ \\
Colostrum day 3 & $1 \cdot 97 \pm 0 \cdot 12$ & $8 \cdot 6 \pm 1 \cdot 1^{*}$ \\
BMSF & $1 \cdot 93 \pm 0 \cdot 64$ & $4 \cdot 1 \pm 0 \cdot 9$ \\
Whey & $2 \cdot 59 \pm 0 \cdot 16$ & $5 \cdot 1 \pm 0 \cdot 8$
\end{tabular}

${ }^{*}$ Significantly different to protein concentration in Day 1 colostrum $(P<0.001)$.

unpublished results). Since betacellulin is expressed in mammary tissue, local synthesis could contribute to milk betacellulin.

The fact that the erbB receptor profile allowing specificity to betacellulin is found in a wide variety of foetal and adult tissues (Quirke et al. 1989, Prigent et al. 1992) and also in some tumours (Jankowski et al. 1992, Fulop et al. 1998, Lee and Maihle 1998) would suggest a significant but an as yet undefined role for betacellulin. Although many biological effects of betacellulin may be due to autocrine or paracrine interaction with receptors, the presence of milk-derived betacellulin suggested that it could be in the circulation. We were not aware of any previous studies that had determined blood betacellulin levels, although a number of studies have reported the presence of EGF in plasma and serum of various species (Perheentupa et al. 1985, Savage et al. 1986). The concentration of betacellulin was approximately eightfold higher in FBS than in newborn serum from 1- and 5 -week-old bull calves. This suggests that betacellulin may be an important foetal endocrine growth factor. Male calves contained detectable serum betacellulin at 1 and 5 weeks of age, but betacellulin concentrations were undetectable in the same animals after 27 weeks of age. Newborn calves were fed milk replacer with a $24 \%$ minimum crude protein composition. This crude protein was derived from whole milk powder and whey powder concentrate. Gastrointestinal absorption of orally administered ${ }^{125}$ I-EGF has been clearly demonstrated in suckling rats (Thornburg et al. 1984). Since we have shown that

Figure 3 Radioimmunoassay of betacellulin; values are means \pm S.E.M.s of triplicate determinations and are expressed as the fraction of ${ }^{125}$ I-betacellulin bound in the absence of competing ligand $\left(B / B_{\mathrm{o}}\right)$. Non-specific binding in the absence of antibody ( $\sim 1 \%$ of total radioactivity) has been subtracted. The competing ligands were (a) recombinant human EGF $(\square)$ and TGF- $\alpha(\bigcirc)$ and $(b)$ competition observed in the presence of increasing dilutions of FBS (-). Each graph also shows the betacellulin standard curve 


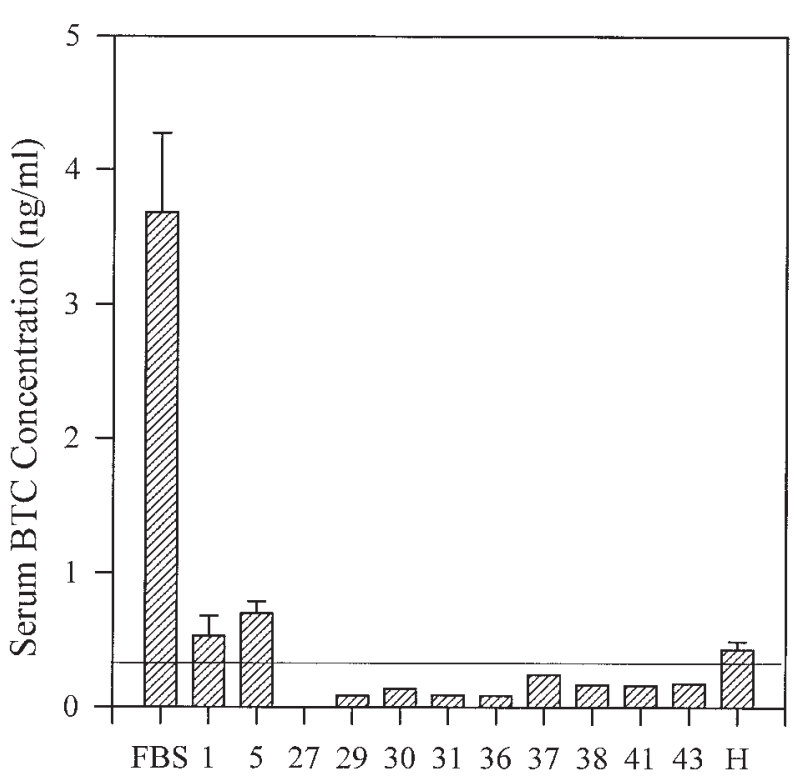

\section{Age (weeks)}

Figure 4 Radioimmunoassay of betacellulin levels in six different batches of FBS, serum from nine steers aged from 1 to 43 weeks and serum from 36 unmated heifers. Data represent the means \pm S.E.M.S of triplicate determinations. The numbers $1-43$ represent the age in weeks of the nine steers at the time of blood collection. The values are shown only for the ten unmated heifers whose serum betacellulin levels were above the minimum detection limit of the assay $(\mathrm{H})$.

milk and whey contain considerable levels of betacellulin, it is possible that the ingested milk replacer could have acted as a source of serum betacellulin in these newborn calves. Alternatively, it is possible that newborn calves produce endogenous betacellulin, but that synthesis decreases due to increasing age, castration or increased clearance from plasma. The data also indicate that gender affects serum betacellulin concentration. The observation that only $27 \%$ of the female animals contained detectable serum betacellulin levels, may indicate that betacellulin could be under control of hormones that regulate oestrus. Studies of EGF blood levels in other species have also reported effects of ontogeny and gender (Perheentupa et al. 1985).

Our findings show that significant levels of betacellulin are present in FBS and that betacellulin is also contained in bovine colostrum, mature milk and cheddar cheese whey. They also indicate that in bovine milk, what was once thought to be EGF might in fact be betacellulin. Although we have not categorically ruled out the possibility that a bovine homologue of another member of the epidermal growth factor family may be responsible for the current results, we think this is unlikely. Since the antibody has a low cross-reactivity to human betacellulin, which shares $88 \%$ sequence homology with bovine betacellulin, it would be unlikely to recognize other bovine EGF family ligands with a lower homology. Although bovine TGF- $\alpha$ has been cloned and sequenced (Zurfluh et al. 1990) we do not believe the peptide is available to test against this betacellulin antibody. The cross-reactivity data indicated that the antibody did not recognize human EGF or human TGF- $\alpha$. Other commercially available EGF ligands are derived from human sequences and, for the reason outlined above, were not tested.

Expression of receptors for betacellulin has been documented in a diverse variety of cell types in several animal species in foetal and neonatal life. These findings lend credence to the hypothesis that betacellulin may be a modulator of foetal and neonatal growth and development. The true significance of betacellulin in bovine milk and foetal serum and the regulation of betacellulin in adult serum require further study.

\section{Acknowledgements}

We are grateful to Kirsty Quinn for her input into the development of the RIA. We greatly appreciate the assistance provided by Mary Pese and colleagues at Rural Services, Roseworthy Campus, University of Adelaide for supplying and collecting blood, colostrum and milk samples. We would also like to thank Dr Annette O'Connor for the steer serum samples, Dr Geoff Regester for supplying bovine cheddar cheese whey and Sam Randles for technical assistance. This work was supported by the Australian Federal Government Cooperative Research Centres Program.

\section{References}

Alimandi M, Wang LM, Bottaro D, Lee CC, Kuo A Frankel M, Fedi P, Tang C, Lippman M \& Pierce JH 1997 Epidermal growth factor and betacellulin mediate signal transduction through co-expressed erbB-2 and erbB-3 receptors. EMBO Journal 16 5608-5617.

Ballard FJ, Grbovac S, Nicholas KR, Owens PC \& Read LC 1995 Differential changes in the milk concentrations of epidermal growth factor and insulin-like growth factor-I during lactation in the Tammar wallaby, Macropus eugenii. General and Comparative Endocrinology 98 262-268.

Barnard JA, Graves-Deal R, Pittelkow MR, DuBois R, Cook P, Ramsey GW, Bishop PR, Damstrup L \& Coffey RJ 1994 Autoand cross induction within the mammalian epidermal growth factor-related peptide family. Journal of Biological Chemistry 269 22817-22822.

Belford DA, Rogers ML, Regester GO, Francis GL, Smithers GW, Liepe IJ, Priebe IK \& Ballard FJ 1995 Milk-derived growth factors as serum supplements for the growth of fibroblast and epithelial cells. In Vitro Cellular and Developmental Biology. Animal 31 750-758.

Berseth CL 1987 Enhancement of intestinal growth in neonatal rats by epidermal growth factor in milk. American Journal of Physiology 253 G662-G665.

Carraway KL 3rd, Weber JL, Unger MJ, Ledesma J, Yu N, Gassmann M \& Lai C 1997 Neuregulin-2, a new ligand of ErbB3/ ErbB4-receptor tyrosine kinases. Nature 387 512-516. 
Carpenter G 1980 Epidermal growth factor is a major growth-promoting agent in human milk. Science 210 198-199.

Chang H, Riese DJ 2nd, Gilbert W, Stern DF \& McMahan UJ 1997 Ligands for ErbB-family receptors encoded by a neuregulin-like gene. Nature 387 509-512.

Connolly JM \& Rose DP 1988 Epidermal growth factor-like proteins in breast fluid and human milk. Life Sciences 42 1751-1756.

Dunbar AJ, Priebe IK, Belford DA \& Goddard C 1999 Identification of betacellulin as a major peptide growth factor in milk: purification, characterization and molecular cloning of bovine betacellulin. Biochemical Journal 344 713-721.

Francis GL, Upton FM, Ballard FJ, McNeil KA \& Wallace JC 1988 Insulin-like growth factors 1 and 2 in bovine colostrum: sequences and biological activities compared with those of a potent truncated form. Biochemical Journal 251 95-103.

Francis GL, Regester GO, Webb HA \& Ballard FJ 1995 Extraction from cheese whey by cation-exchange chromatography of factors that stimulate the growth of mammalian cells. Journal of Dairy Science 78 1209-1218.

Fulop V, Mok SC, Genest DR, Szigetvari I, Berkowitz RS \& Cseh I 1998 c-myc, c-erbB-2, c-fms and bcl-2 oncoproteins. Expression in normal placenta, partial and complete mole and choriocarcinoma. Journal of Reproductive Medicine 43 101-110.

Gargosky SE, Walton PE, Owens PC, Wallace JC \& Ballard FJ 1990 Insulin-like growth factor-I (IGF-I) and IGF binding proteins both decline in the rat during late pregnancy. Journal of Endocrinology 127 383-390.

Grueters A, Alm J, Lakshmanan J \& Fisher DA 1985 Epidermal growth factor in mouse milk during early lactation: lack of dependency on submandibular glands. Pediatric Research 8 853-856.

Higashiyama S, Horikawa M, Yamada K, Ichino N, Nakano N, Nakagawa T, Miyagawa J, Matsushita N, Nagatsu T, Taniguchi N \& Ishiguro H 1997 A novel brain-derived member of the epidermal growth factor family that interacts with ErbB3 and ErbB4. Journal of Biochemistry (Tokyo) 122 675-680.

Iacopetta BJ, Grieu F, Horisberger M and Sunahara GI 1992 Epidermal growth factor in human and bovine milk. Acta Paediatrica 81 287-291.

Jaeger MA, Lamar CH, Bottoms GD \& Cline TR 1987 Growth stimulating substances in porcine milk. American Journal of Veterinary Research 48 1531-1533.

Jankowski J, Coghill G \& Wormsley KG 1992 Oncogenes and oncosuppressor genes in adenocarcinoma of the oesophagus. Gut 33 1033-1038.

Jansson L, Karlson FA \& Westermark B 1985 Mitogenic activity and epidermal growth factor content in human milk. Acta Paediatrica Scandinavia 74 250-253.

Kataoka H, Joh T, Kasugai K, Okayama N, Moriyama A, Asai K \& Kato T 1998 Expression of mRNA for heregulin and its receptor, erbB-3 and erbB-4, in human upper gastrointestinal mucosa. Life Sciences 63 553-564.

King R, Wells JRE, Krieg P, Snoswell M, Brazier J, Bagley CJ, Wallace JC, Ballard FJ, Ross M \& Francis GL 1992 Production and characterization of recombinant insulin-like growth factor-I (IGF-I) and potent analogues of IGF-I, with Gly or Arg substituted for $\mathrm{Glu}^{3}$, following their expression in Escherichia coli as fusion proteins. Journal of Molecular Endocrinology 8 29-41.

Lee CY, Head HH, Feinstein CR, Hayen J \& Simmen FA 1995 Endocrine changes and circulating insulin-like growth factors in newborn calves fed colostrum, milk or milk replacer. AsianAustralasian Journal of Animal Sciences 8 51-56.

Lee H \& Maihle NJ 1998 Isolation and characterization of four alternate c-erbB3 transcripts expressed in ovarian carcinoma-derived cell lines and normal human tissues. Oncogene 16 3243-3252.

Luetteke TH, Qiu RL, Fenton SE, Troyer KL, Riedel RF, Chang A \& Lee DC 1999 Targeted inactivation of the EGF and amphiregulin genes reveals distinct roles for EGF receptor ligands in mouse mammary gland development. Development 126 2739-2750.
Malven PV, Head HH, Collier RJ \& Buonomo FC 1987 Periparturient changes in secretion and mammary uptake of insulin and in concentrations of insulin and insulin-like growth factors in milk of dairy cows. Journal of Dairy Science 70 2254-2260.

Marchionni MA, Goodearl AD, Chen MS, Bermingham-McDonough O, Kirk C, Hendricks M, Danehy F, Misumi D, Sudhalter J \& Kobayashi K 1993 Glial growth factors are alternatively spliced erbB2 ligands expressed in the nervous system. Nature $\mathbf{3 6 2}$ 312-318.

McCuskey RS, Nishida J, McDonnell D, Williams C \& Koldovsky O 1997 Effect of milk-borne epidermal growth factor on the hepatic microcirculation and Kupffer cell function in suckling rats. Biology of the Neonate 71 202-206.

Mielke S, Meden H \& Kuhn W 1998 Expression of the c-erbB-2encoded oncoprotein p185 (HER-2/neu) in pregnancy as a model for oncogene-induced carcinogenesis. Medical Hypotheses 50 359-362.

Noguchi H, Sakamoto C, Wada K, Akamatsu T, Uchida T, Tatsuguchi A, Matsui H, Fuhui H, Fujimori T \& Kasuga M 1999 Expression of heregulin $\alpha$, and erbB-2, and erbB-3 and their influences on proliferation of gastric epithelial cells. Gastroenterology 117 1119-1127.

Okada M, Ohmura E, Kamiya Y, Murakami H, Onoda N, Iwashita M, Wakai K, Tsushima T \& Shizume K 1991 Transforming growth factor (TGF)- $\alpha$ in human milk. Life Sciences 48 1151-1156.

Okamoto S \& Oka T 1985 Effect of pregestational sialoadenectomy of nursing mothers on eyelid opening of pups. American Journal of Physiology 249 R285-R289.

O'Keefe E, Hollenberg MD \& Cuatrecasas P 1974 Epidermal growth factor. Characteristics of specific binding in membranes from liver, placenta, and other target tissues. Archives of Biochemistry and Biophysics 164 518-526.

Okuyama H, Urao M, Lee D, Drongowski RA \& Coran AG 1998 The effect of epidermal growth factor on bacterial translocation in newborn rabbits. Journal of Pediatric Surgery 33 225-228.

Oliver MH, Harrison NK, Bishop JE, Cole PJ \& Laurent GJ 1989 A rapid and convenient assay for counting cells cultured in microwell plates: application for assessment of growth factors. Journal of Cell Science 92 513-518.

Perheentupa J, Lakshmanan J, Hoath SB, Beri U, Kim H, Macaso T \& Fisher DA 1985 Epidermal growth factor measurements in mouse plasma: method, ontogeny, and sex difference. American Journal of Physiology 248 E391-E396.

Pinkas-Kramarski R, Lenferink AE, Bacus SS, Lyass L, van de Poll ML, Klapper LN, Tzahar E, Sela M, van Zoelen EJ \& Yarden Y 1998 The oncogenic ErbB-2/ErbB-3 heterodimer is a surrogate receptor of the epidermal growth factor and betacellulin. Oncogene 16 1249-1258.

Popliker M, Shatz A, Avivi A, Ullrich A, Schlessinger J \& Webb CE 1987 Onset of endogenous synthesis of epidermal growth factor in neonatal mice. Developmental Biology 119 38-44.

Prigent SA, Lemoine NR, Hughes CM, Plowman GD, Selden C \& Gullick WJ 1992 Expression of the c-erbB-3 protein in normal adult and fetal tissues. Oncogene 7 1273-1278.

Quirke P, Pickles A, Tuzi NL, Mohamedee O \& Gullick WJ 1989 Pattern of expression of c-erbB-2 oncoprotein in human fetuses. British Journal of Cancer 60 64-69.

Raab G \& Klagsbrun M 1997 Heparin-binding EGF-like growth factor. Biochimica Biophysica Acta 1333 F179-F199.

Raaberg L, Nexo E, Tollund L, Poulsen SS, Christensen SB \& Christensen MS 1990 Epidermal growth factor reactivity in rat milk. Regulatory Peptides 30 149-157.

Read LC, Upton FM, Francis GL, Wallace JC, Dahlenberg GW \& Ballard FJ 1984 Changes in the growth-promoting activity of human milk during lactation. Pediatric Research 18 133-139.

Read LC, Francis GL, Wallace JC \& Ballard FJ 1985 Growth factor concentrations and growth-promoting activity in human milk following premature birth. Journal of Developmental Physiology 7 $135-145$. 
Riese DJ 2nd, Bermingham Y, van Raaij TM, Buckley S, Plowman GD \& Stern DF 1996 Betacellulin activates the epidermal growth factor receptor and erbB-4, and induces cellular response patterns distinct from those stimulated by epidermal growth factor or neuregulin- $\beta$. Oncogene 12 345-353.

Sasada R, Ono Y, Taniyama Y, Shing Y, Folkman J \& Igarashi K 1993 Cloning and expression of cDNA encoding human betacellulin, a new member of the EGF family. Biochemical and Biophysical Research Communications 190 1173-1179.

Savage AP, Chatterjee VK, Gregory H \& Bloom SR 1986 Epidermal growth factor in blood. Regulatory Peptides 16 199-206.

Seno M, Tada H, Kosaka M, Sasada R, Igarashi K, Shing Y, Folkman J, Ueda M \& Yamada H 1996 Human betacellulin, a member of the EGF family dominantly expressed in pancreas and small intestine, is fully active in a monomeric form. Growth Factors 13 181-191.

Shen WH \& Xu RJ 1996 Stability of epidermal growth factor in the gastrointestinal lumen of suckling and weaned pigs. Life Sciences 59 197-208.

Shen WH \& Xu RJ 1998 Stability and distribution of orally administered epidermal growth factor in neonatal pigs. Life Sciences 63 809-820.

Shing Y, Christofori G, Hanahan D, Ono Y, Sasada R, Igarashi K \& Folkman J 1993 Betacellulin: a mitogen from pancreatic $\beta$ cell tumors. Science 259 1604-1607.

Shing YW \& Klagsbrun M 1984 Human and bovine milk contain different sets of growth factors. Endocrinology 115 273-282.

Spitzer E \& Grosse R 1987 EGF receptors on plasma membranes purified from bovine mammary gland of lactating and pregnant animals. Biochemistry International 14 581-586.

Thornburg W, Matrisian L, Magun B \& Koldovsky O 1984 Gastrointestinal absorption of epidermal growth factor in suckling rats. American Journal of Physiology 246 G80-G85.
Vega JR, Gibson CA, Skaar TC, Hadsell DD \& Baumrucker CR 1991 Insulin-like growth factor (IGF)-I and -II and IGF binding proteins in serum and mammary secretions during the dry period and early lactation in dairy cows. Journal of Animal Science $\mathbf{6 9}$ 2538-2544.

Wang DP, Fujii S, Konishi I, Nanbu Y, Iwai T, Nonogaki H \& Mori T 1992 Expression of c-erbB-2 protein and epidermal growth factor receptor in normal tissues of the female genital tract and in the placenta. Virchows Archiv. A, Pathological Anatomy and Histopathology 420 385-393.

Watanabe T, Shintani A, Nakata M, Shing Y, Folkman J, Igarashi K \& Sasada R 1994 Recombinant human betacellulin: molecular structure, biological activities and receptor interaction. Journal of Biological Chemistry 269 9966-9973.

Yagi H, Suzuki S, Noji T, Nagashima K \& Kuroume T 1986 Epidermal growth factor in cow's milk and milk formulas. Acta Paediatrica Scandinavia 75 233-235.

Zhang D, Sliwkowski MX, Mark M, Frantz G, Akita R, Sun Y, Hillan K, Crowley C, Brush J \& Godowski PJ 1997 Neuregulin-3 (NRG3): a novel neural tissue-enriched protein that binds and activates ErbB4. PNAS 94 9562-9567.

Zurfluh LL, Bolten SL, Byatt JC, McGrath MF, Tou JS, Zupec ME \& Krivi GG 1990 Isolation of genomic sequence encoding a biologically active bovine TGF-alpha protein. Growth Factors 3 257-266.

Received 15 June 2000

Accepted 6 October 2000 